even reported that his strength had succumbed to the trial. But letters from him up to a period just before his starting to return led to the hope that he had quite recovered from this attack. But it was not permitted to him to reach his friends again, and he died as stated, amid some of the wildest scenery of the hills he loved so dearly, on the 19th June.

Few men have been more thoroughly saturated with the love of their pursuits and of nature than was Stoliczka. It was this which rendered his influence, always for good, much more widely felt than merely in his own department. There, too, his unremitting devotion and earnest labours were the strongest stimulant to others to do their best, in order to keep pace with him; but this influence had also made itself felt by every cultivator of natural science in India. For several years Stoliczka was Natural History Secretary to the Asiatic Society of Bengal, and it is mainly to his exertions that this Society owes its resumption of much of its early vigour. Its journal for years past is full of contributions of high value from his pen in almost every branch of natural history. How highly his services were appreciated and valued by his colleagues will be best seen in the reports of the Geological Survey and of the Asiatic Society, while his happy disposition and the genial sociality of his temperament, coupled with the inflexible rectitude of his character, rendered him a general favourite. Cut off at the early age of 35 , few men will be more deeply regretted by those who had the privilege of knowing him, few will be more truly missed than Ferdinand Stoliczka.

\title{
CORRESPOINDEITCE.
}

\section{RAISED BEACHES AND ANCIENT IRISH VOLCANOS.}

Sir,-The Geological Magazine for May, 1874, has just come to hand. With reference to Mr. Hardman's paper, p. 215, paragraph second, he will find another case of raised beach and submarine peat, also on the south coast of Ireland, mentioned in Quart. Journ. Geol. Soc. Lond. vol. xxiv. p. 4 ; also in Gror. MAG. 1867, Vol. IV. p. 8 ; May, 1868, p. 244; October, 1868, p. 484.

It would be interesting if any concordance could be found between the phenomena of the two places, though I cannot recall any evidence of three submergences at the one I refer to near Youghal.

In Professor Hull's address, in the same Number, p. 205, I presume he did not intend to notice all the volcanic eruptions of Carboniferous times in Ireland or he would not have omitted to mention Croghan Hill, near Phillipstown, thought by the late Professor Jukes to be the funnel of an old volcano. A. B. Wynn.

MurRee, Panjab, June $10 t h, 1874$.

Mr. Joseph Prestwich, F.R.S., F.G.S., has been appointed to the office of Professor of Geology in the University of Oxford, as successor to the late Prof. Phillips.

The Council of the Institution of Civil Engineers have awarded a Telford Medal and a Telford Premium to Prof. Prestwich, F.R.S., Assoc. Inst. C.E., for his paper, "On the Geological Conditions affecting the Construction of a Tunnel between England and France." 